\title{
Verb complementation in English
}

\section{[Slovesna komplementacia $\mathrm{v}$ anglictine]}

\author{
Ludmila Jancovicova
}

DOI: 10.18355/XL.2019.12.02.06

\begin{abstract}
This comparative study aims to provide a detailed analysis of various approaches of linguists regarding the issues of verb complementation and valency in English. Furthermore, the issues related to verb complementation terminology, clause structure, verb categories, and clause patterns are analyzed and discussed as well. The structural approach to verb complementation is closely related to the classification of verbs into verb categories, namely categories of copular verbs, intransitive verbs and transitive verbs. The verb category determines the number and type of other complements in a sentence. Each sentence consists of a certain number of clause elements whose presence is obligatory for the sentence to be grammatical. Moreover, particular attention is paid to the reasons for a different classification of complementation types in selected linguistic sources of literature. Lastly, the verb complementation types with the focus on the formal realization of obligatory complements and their functions are also analyzed and discussed.
\end{abstract}

Key words: verb complementation, complement, clause structure, verb category, clause pattern

\section{Anotácia}

Ciel’om tejto komparatívnej štúdie je poskytnút' podrobnú analýzu rôznych prístupov lingvistov k problematike slovesnej komplementácie a valencie v angličtine. Okrem toho, $\mathrm{v}$ štúdii sú tiež analyzované a diskutované otázky týkajúce sa terminológie slovesnej komplementácie, vetnej stavby, slovesných kategórií a vetných vzorcov. Štrukturálny prístup $\mathrm{k}$ slovesnej komplementácii je úzko spojený s klasifikáciou slovies do slovesných kategórií, menovite kategórií sponových slovies, netranzitívnych slovies a tranzitívnych slovies. Slovesná kategória určuje počet a typ d'alších komplementov vo vete. Každá veta pozostáva z určitého počtu vetných členov, prítomnost' ktorých je záväzná kvôli gramatickej a významovej správnosti vety. Okrem toho, osobitná pozornost' je venovaná dôvodom odlišnej klasifikácie typov komplementácie vo vybraných lingvistických zdrojoch literatúry. Nakoniec, v štúdii sú tiež analyzované a diskutované jednotlivé typy komplementácie s dôrazom na formálnu realizáciu obligatórnych komplementov a ich funkcií.

Kl’účové slovesá: slovesná komplementácia, komplement, vetná stavba, slovesná kategória, vetný vzorec

\section{Úvod}

V tejto štúdii sú analyzované a porovnávané rôzne prístupy lingvistov k problematike slovesnej komplementácie a valencie v angličtine. Niektorí lingvisti, napríklad Quirk a kol. (1985), Greenbaum a Nelson (2002), Carter a McCarthy (2006), používajú termín slovesná komplementácia a zaoberajú sa iba tými členmi vetnej stavby, ktoré vo vete nasledujú po slovese, sú na slovese závislé a sú nevyhnutné k tomu, aby bola veta z hl'adiska gramatického ako aj sémantického úplná. Naopak, Biber a kol. (1999), Huddleston a Pullum (2002), Downing a Locke (2006) a Wekker a Haegeman (1985), používajú termín valencia. Podl'a týchto lingvistov a ich valenčnej teórie patria medzi komplementy nielen tie časti vety, ktoré nasledujú po slovese, ale aj tá čast' vety, ktorá má v anglickej oznamovacej 
vete postavenie pred slovesom a $\mathrm{v}$ opytovacej vete postavenie za pomocným slovesom, resp. modálnym slovesom, a to je podmet. V štúdii je tiež analyzovaná a porovnávaná odlišná terminológia používaná lingvistami zaoberajúcimi sa problematikou slovesnej komplementácie a valencie. Náležitá pozornost' je tiež venovaná vetnej stavbe a syntaktickým charakteristikám obligatórnych a fakultatívnych vetných členov. V štúdii sú tiež analyzované dôvody odlišnej klasifikácie komplementačných typov. Quirk a kol. (1985), Carter a McCarthy (2006) prezentujú štyri typy slovesnej komplementácie - sponovú (copular complementation), monotranzitívnu (monotransitive complementation), ditranzitívnu (ditransitive complementation) a komplexne-tranzitívnu komplementáciu (complex transitive complementation). Avšak, Biber a kol. (1999), Huddleston a Pullum (2002) a Downing a Locke (2006) uvádzajú pät' typov slovesnej komplementácie netranzitívnu, sponovú, monotranzitívnu, ditranzitívnu a komplexne-tranzitívnu komplementáciu. V štúdii je tiež analyzovaná klasifikácia typov komplementácie podl'a Wekkera a Haegemanovej (1985), ktorí prezentujú až sedem typov slovesnej komplementácie. Problematika slovesnej komplementácie a valencie je analyzovaná, porovnávaná a diskutovaná na autentických vetných príkladoch excerpovaných z Longman Dictionary of Contemporary English Online (d’alej LDOCE).

\section{Slovesná komplementácia a valencia}

Pod pojmom slovesná komplementácia $\mathrm{v}$ širšom zmysle slova rozumieme to, že správna anglická veta môže byt' vytvorená iba vtedy, ak je sloveso s určitým slovesným tvarom, okrem netranzitívneho slovesa, doplnené istým počtom d'alších konštituentov, ktoré sú potrebné na doplnenie významu vety.

Vo vetách s výskytom sponových slovies a tranzitívmych slovies všetkých typov (monotranzitívne, ditranzitívne a komplexne-tranzitívne slovesá) je hlavná úloha prisudzovaná slovesám, pretože tieto slovesá určujú počet a typ d’alších konštituentov vo vete. Každá hlavná veta sa skladá z určitého počtu vetných členov, ktorých prítomnost' vo vete je záväzná (obligatórna) kvôli gramatickej a sémantickej správnosti vety.

Quirk a kol. (1985), Carter a McCarthy (2006), ktorí sa zaoberajú problematikou slovesnej komplementácie, venujú pozornost' iba tým častiam vety, ktoré nasledujú po slovese. Ak sú tieto časti vety, resp. komplementy (complements) v postavení za slovesom na slovese závislé a sú potrebné $\mathrm{k}$ tomu, aby bola veta úplná z hl'adiska štruktúry ako aj z hl'adiska významu, hovoríme o slovesnej komplementácii (verb complementation).

Naopak, Biber a kol. (1999), Huddleston a Pullum (2002), Downing a Locke (2006) a Wekker a Haegeman (1985) používajú termín valencia (valency) a za komplementy pokladajú nielen tie časti vety, ktoré nasledujú po slovese, ale aj tú čast' vety, ktorá má v anglickej oznamovacej vete postavenie pred slovesom, a to je podmet.

Carter and McCarthy (2006:496) tvrdia, že „komplementácia sa týka tých vetných členov, ktoré v oznamovacej vete nasledujú po slovese a sú potrebné na doplnenie významu slovesa, resp. významu celej vety. Niektoré slovesá sú významovo úplné samé o sebe a nevyžadujú žiadnu komplementáciu (používajú sa ako netranzitívne slovesá), iné slovesá vyžadujú komplementáciu jedným vetným členom (single complementation) alebo komplementáciu dvomi vetnými členmi (dual complementation).“

Biber a kol. (1999:141) v ich charakteristike valencie rozlišujú medzi ,jednomiestnymi slovesami (slovesami kombinujúcimi sa iba s podmetom), dvoj-miestnymi slovesami (slovesami kombinujúcimi sa s podmetom a iným vetným členom) a trojmiestnymi slovesami (slovesami kombinujúcimi sa s podmetom a dvomi d'alšími vetnými členmi)." Podl'a valenčnej teórie, podobne ako podl'a teórie slovesnej

XLinguae, Volume 12, Issue 2, April 2019, ISSN 1337-8384, eISSN 2453-711X 
komplementácie, rozlišujeme slovesá sponové, netranzitívne a tranzitívne. Podl'a lingvistov uplatňujúcich teóriu valencie sú slovesá, ktoré sa vyskytujú v jednomiestnych vetných vzorcoch (one-place patterns) netranzitívne slovesá, slovesá vyskytujúce sa $\mathrm{v}$ dvoj-miestnych vetných vzorcoch (two-place patterns) sú sponové slovesá a slovesá $\mathrm{v}$ troj-miestnych vetných vzorcoch (three-place patterns) sú tranzitívne slovesá.

V niektorých zdrojoch literatúry sa uvádza, že minimálna vetná štruktúra sa skladá z podmetu a slovesa. Avšak, k tejto simplifikovanej definícii je potrebné dodat', že ak sa minimálna vetná štruktúra skladá iba $\mathrm{z}$ podmetu a slovesa, sloveso musí byt' netranzitívne. Netranzitívne slovesá si nevyžadujú doplnenie (komplementáciu) d’alšími obligatórnymi vetnými členmi. Avšak, ostatné slovesné kategórie, sponové slovesá a tranzitívne slovesá, si takéto doplnenie vyžadujú.

Termín komplement (complement) sa používa v syntaktickej teórii vo viacerých významoch. Pod týmto termínom rozumieme komplement ako obligatórny vetný člen po sponových slovesách a po komplexne-tranzitívnych slovesách. Po sponových slovesách môžu v angličtine nasledovat' iba dva obligatórne vetné členy, a tými sú podmetový doplnok (subject complement), alebo príslovkové určenie (adverbial). Obligatórnymi vetnými členmi po komplexne-tranzitívnych slovesách sú dva vetné členy, a to priamy predmet (direct object) a predmetový doplnok (object complement), alebo priamy predmet (direct object) a príslovkové určenie (adverbial). Avšak, termín komplement sa používa $\mathrm{v}$ lingvistických zdrojoch literatúry aj vo význame komplement ako ktorýkol'vek iný vetný člen, ktorý je obligatórnym vetným členom aj po iných slovesách, nielen po sponových a komplexne-tranzitívnych slovesách.

$\mathrm{V}$ tejto štúdii, ako už bolo konštatované, porovnávame rôzne prístupy lingvistov $\mathrm{k}$ problematike slovesnej komplementácie a valencie, analyzujeme a porovnávame rôzne typy slovesnej komplementácie. Okrem toho, porovnávame odlišnú terminológiu týkajúcu sa analyzovanej problematiky vo vybraných lingvistických zdrojoch literatúry a analyzujeme gramatickú realizáciu obligatórnych vetných členov $\mathrm{v}$ jednotlivých typoch komplementácie. Ked’že terminológia používaná lingvistami vo vybraných zdrojoch lingvistickej literatúry nie je jednotná, v analýze a interpretácii vetných príkladov excerpovaných z Longman Dictionary of Contemporary English Online budeme používat' terminológiu Quirka a kol. (1985).

[1] Air pollution will become [a major problem] (LDOCE). Znečistenie ovzdušia sa stane vážnym problémom.

[2] The house was [empty] for many years and fell [into disrepair] (LDOCE). Dom bol po mnoho rokov prázdny a upadol do havarijného stavu.

[3] I now declare [this factory] [open] (LDOCE).

Teraz vyhlasujem túto továreň za otvorenú.

[4] Pneumonia put [him] [in the hospital] for a week (LDOCE).

Pneumónia ho priviedla na týždeň do nemocnice.

[5] Where did you buy [that dress ?] (LDOCE).

Kde si kúpil/a tie šaty?

[6] She gave [me] [some information on university courses] (LDOCE). Poskytla mi nejaké informácie o univerzitných kurzoch.

Sponové sloveso to become (stat' sa) si vo vete [1] vyžaduje doplnenie obligatórnym vetným členom, a to je podmetový doplnok a major problem. Podmetový doplnok sa 
vyskytuje $\mathrm{v}$ angličtine iba po sponových slovesách a môže byt' vyjadrený nominálnou frázou alebo adjektívnou frázou. V uvedenom vetnom príklade je podmetový doplnok vyjadrený nominálnou frázou. Ďalšou charakteristickou črtou podmetového doplnku (subject complement) je to, ako to vyplýva aj z názvu termínu, že dopíňa význam vyjadrený podmetom.

Vo vete [2] sa sponové sloveso vyskytuje v obidvoch vetách prirad'ovacieho súvetia. Po sponovom slovese to be (byt') $\mathrm{v}$ tvare minulého času nasleduje $\mathrm{v}$ prvej vete prirad'ovacieho súvetia podmetový doplnok vyjadrený prídavným menom empty (prázdny) a po slovese to fall (padat', padnút', upadat', upadnút') $\mathrm{v}$ druhej vete prirad'ovacieho súvetia nasleduje príslovkové určenie into disrepair. Príslovkové určenie sa vo vetnom príklade [2] vyskytuje dvakrát, raz ako fakultatívny vetný člen, ktorý možno vo vete aj vynechat' for many years a druhý raz ako obligatórny vetný člen into disrepair, vynechanie ktorého by spôsobilo gramatickú a sémantickú neúplnost' vety. $\mathrm{V}$ obidvoch prípadoch je príslovkové určenie vyjadrené prepozicionálnou frázou.

Komplexne-tranzitívne sloveso to declare (vyhlásit') si vo vete [3] vyžaduje doplnenie dvomi obligatórnymi vetnými členmi, a to priamym predmetom this factory a predmetovým doplnkom open. Priamy predmet je vyjadrený nominálnou frázou a predmetový doplnok je vyjadrený adjektívnou frázou. Ďalšou kombináciou obligatórnych vetných členov, ktorá sa môže vyskytovat' po komplexne-tranzitívnych slovesách je kombinácia priameho predmetu a príslovkového určenia. Vo vete [4] nasleduje po komplexne-tranzitívnom slovese to put priamy predmet him, obligatórne príslovkové určenie in the hospital a fakultatívne príslovkové určenie for a week. Priamy predmet je vo vete [4] vyjadrený nominálnou frázou. Obe príslovkové určenia, obligatórne a aj fakultatívne, sú $\mathrm{v}$ uvedenej vete vyjadrené prepozicionálnymi frázami.

Z uvedenej analýzy vyplýva, že vo vetách [1] -[4] sa termín komplement používa vo význame komplement ako obligatórny vetný člen po sponových a komplexnetranzitívnych slovesách. Avšak, vo vetách [5] a [6] sa termín komplement používa vo význame komplement ako ktorýkol'vek iný vetný člen, ktorý je obligatórnym vetným členom aj po iných slovesách. Vo vete [5] nasleduje po monotranzitívnom slovese to buy (kupovat', kúpit') priamy predmet that dress, ktorý je obligatórnym komplementom slovesa to buy. Sloveso to give (dat', poskytnút') vo vete [6] je ditranzitívnym slovesom, ktoré si vyžaduje komplementáciu nepriamym predmetom me a priamym predmetom some information on university courses.

\section{Klasifikácia typov komplementácie}

Analýzou vybraných gramatík zaoberajúcich sa problematikou slovesnej komplementácie a valencie $\mathrm{v}$ angličtine sme dospeli k záveru, že ani názory lingvistov na typy slovesnej komplementácie nie sú jednotné. Carter a McCarthy (2006:508) uvádzajú, že „komplementácia sa týka predovšetkým tranzitívnych a sponových konštrukcií, ked’že netranzitívne slovesné konštrukcie si nevyžadujú žiadnu komplementáciu.

\section{Monotranzitívna komplementácia:} sloveso + priamy predmet

2. Ditranzitívna komplementácia:

sloveso + nepriamy predmet a priamy predmet

sloveso + priamy predmet + prepozicionálna fráza (transitive-obligue construction)

3. Komplexne-tranzitívna komplementácia:

sloveso + priamy predmet + predmetový doplnok 
sloveso + priamy predmet + lokatívny komplement

4. Sponová komplementácia:

sponové sloveso (napríklad be, look, seem) + podmetový doplnok.“

Carter a McCarthy v gramatike Cambridge Grammar of English (ibid.) uznávajú štyri typy slovesnej komplementácie - monotranzitívnu, ditranzitívnu, komplexnetranzitívnu a sponovú komplementáciu. Súhlasíme $\mathrm{s}$ klasifikáciou typov komplementácie a vetných vzorcov týchto lingvistov, avšak $\mathrm{v}$ sponovej komplementácii nám chýba vetný vzorec sponové sloveso + lokatívny komplement.

Quirk a kol. v gramatike A Comprehensive Grammar of the English Language (1985), podobne ako Carter a McCarthy (2006), tiež tvrdia, že v angličtine sú štyri typy slovesnej komplementácie, a to monotranzitívna, ditranzitívna, komplexne-tranzitívna a sponová komplementácia. Avšak, v sponovej komplementácii uvádzajú okrem vetného vzorca sponové sloveso + podmetový doplnok aj vetný vzorec sponové sloveso + príslovkové určenie.

Avšak, Biber a kol. v gramatike Longman Grammar of Spoken and Written English (1999) a Downing a Locke v gramatike English Grammar. A University Course. (2006) rozlišujú pät typov komplementácie: intranzirívnu, monotranzitívnu ditranzitívnu, komplexne-tranzitívnu a sponovú komplementáciu. Uvedení lingvisti zarad'ujú intranzitívnu komplementáciu ku komplementačným typom, ked’že valenčná teória, na rozdiel od teórie slovesnej komplementácie, zarad’uje do vetnej štruktúry nielen vetné členy v postavení za slovesom, ale aj vetný člen v postavení pred slovesom.

Wekker a Haegeman v gramatike A Modern Course of English Syntax (1985) rozlišujú až sedem typov komplementácie:

1. Intranzitívna: He laughed.

2. Sponová: He seemed very cheerful.

3. Monotranzitívna: He killed the mouse.

4. Ditranzitívna: He gave the girl a book.

5. Komplexne-tranzitívna: He called him a fool.

6. Intranzitívna + prepozicionálna fráza: He leaned towards the girl.

7.Tranzitívna + prepozicionálna fráza: He put his head on her shoulder (1985: 64-65).

Z analýzy komplementačných typov podl'a Wekkera a Haegemanovej (1985) vyplýva, že títo lingvisti zarad'ujú medzi komplementačné typy aj netranzitívnu komplementáciu, podobne ako Biber a kol. (1999) a Downing a Locke (2006). Avšak, uvádzajú ešte dva d’alšie typy komplementácie, a to typ intranzitívna komplementácia + prepozicionálna fráza a typ tranzitívna komplementácia + prepozicionálna fráza. Tieto typy komplementácie nie sú uvedené v žiadnych iných lingvistických zdrojoch literatúry, ktoré sa zaoberajú problematikou slovesnej komplementácie a valencie $\mathrm{v}$ angličtine.

Podl'a našej interpretácie je typ intranzitívna komplementácia + prepozicionálna fráza vo vete He leaned towards the girl (Wekker a Haegeman, 1985: 64-65) typom monotranzitívnej komplementácie, $\mathrm{v}$ ktorej po monotranzitívnom slovese to lean towards (nakláňat' sa) nasleduje prepozicionálny predmet girl. Ked’že prepozicionálny predmet je $\mathrm{v}$ monotranzitívnom type komplementácie obligatórnym vetným členom, môžeme ho nazvat' aj prepozicionálnym komplementom.

Diskutabilný je tiež typ tranzitívna komplementácia + prepozicionálna fráza vo vete He put his head on her shoulder (Wekker a Haegeman, 1985). Podl'a našej interpretácie je to typ komplexne-tranzitívnej komplementácie, $\mathrm{v}$ ktorej po komplexne-tranzitívnom slovese to put (položit') nasledujú dva obligatórne vetné členy, resp. komplementy, a to priamy predmet a príslovkové určenie (podl'a 
terminológie Quirka a kol. (1985), resp. priamy predmet a lokatívny komplement (podl'a terminológie Cartera a McCarthyho (2006).

[7] Gemma was reading (LDOCE). Gemma čítala.

[8] Don't worry, I'll look after [the kids] tomorrow (LDOCE). Neboj(te) sa, zajtra sa o deti postarám.

[9] I don't want to put [you] [in danger] (LDOCE).

Nechcem t'a/vás vystavit' nebezpečenstvu.

Z analýzy vybraných lingvistických zdrojov literatúry tiež vyplýva, že typy komplementácie vo vetných príkladoch [7], [8], [9] by boli viacerými lingvistami interpretované odlišne. Quirk a kol., Carter a McCarthy by vetu [7] nepokladali za komplementáciu, pretože sloveso to read (čítat') si v tejto vete nevyžaduje doplnenie žiadnym obligatórnym vetným členom. Naopak, Biber a kol., Huddleston a Pullum, Downing a Locke, Wekker a Haegeman by pokladali uvedenú vetu za typ intranzitívnej komplementácie, pretože za komplement pokladajú nielen tú čast' vety, ktorá nasleduje po slovese, ale aj tú čast' vety, ktorá je v anglickej oznamovacej vete pred slovesom, teda podmet.

Veta [8] by bola podl'a klasifikácie Wekkera a Haegemanovej interpretovaná ako typ intranzitívna komplementácia + prepozicionálna fráza. Avšak u všetkých ostatných lingvistov uvedených vyššie by bola tá istá veta pokladaná za typ monotranzitívnej komplementácie, $\mathrm{v}$ ktorej po prepozicionálnom slovese nasleduje predmet prepozicionálny predmet, resp. prepozicionálny komplement (prepositional complement).

Z analýzy tiež vyplýva, že veta [9] by bola takisto z pohl’adu typu komplementácie interpretovaná viacerými lingvistami odlišne. Wekker a Haegeman by ju pokladali za typ tranzitívna komplementácia + prepozicionálna fráza a ostatní lingvisti uvedení vyššie by ju pokladali za komplexne-tranzitívnu komplementáciu, v ktorej po slovese to put nasleduje priamy predmet a príslovkové určenie, resp. priamy predmet a lokatívny komplement (podl'a terminológie Cartera a McCarthyho, 2006).

\section{Analýza typov komplementácie}

V tejto časti je pozornost' venovaná jednotlivým typom slovesnej komplementácie, vetným vzorcom (clause pattens) a tiež gramatickej realizácii obligatórnych vetných členov, ktoré nasledujú po slovese.

\section{Sponová komplementácia}

Nejednotnost' lingvistov, ktorá sa týka problematiky slovesnej komplementácie a valencie sa prejavuje aj v nejednotnej terminológii týkajúcej sa obligatórnych vetných členov v analyzovaných lingvistických zdrojoch literatúry. Obligatórny vetný člen, ktorý nasleduje v sponovej komplementácii (copular complementation) po sponovom slovese je označovaný termínom podmetový doplnok (subject complement) v nasledovných lingvistických zdrojoch literatúry: A Comprehensive Grammar of the English Language, (Quirk a kol., 1985), Cambridge Grammar of English, (Carter a McCarthy, 2006), English Grammar. A University Course, (Downing a Locke, 2006). Avšak, tento istý obligatórny vetný člen je označovaný termínom predikatívny komplement (predicative complement) v gramatike A Modern Course in English Syntax, (Wekker a Haegeman, 1985).

Quirk a kol. (1985) uvádzajú, že v sponovej komplementácii môže po sponovom slovese nasledovat' nielen podmetový doplnok (subject complement), ale aj 
príslovkové určenie (adverbial). Oba vetné členy sú obligatórnymi vetnými členmi vo vetných vzorcoch SVC (podmet-sloveso-komplement) a SVA (podmet - slovesopríslovkové určenie). Príslovkové určenia vo vetnom vzorci SVA sú väčšinou príslovkové určenia miesta a času.

Ak porovnávame sponovú komplementáciu prezentovanú $\mathrm{v}$ gramatike A Comprehensive Grammar of the English Language, (Quirk a kol., 1985), so sponovou komplementáciou v gramatike Cambridge Grammar of English, (Carter a McCarthy, 2006), môžeme konštatovat', že Carter a McCarthy (2006) nerozlišujú, na rozdiel od Quirka a kol. (1985), vetný vzorec SVA (podmet - sloveso - príslovkové určenie). Obligatórne príslovkové určenie v postavení za sponovým slovesom pokladajú títo lingvisti za podmetový doplnok (subject complement) vyjadrený príslovkovou frázou alebo prepozicionálnou frázou.

[10] We remained [friends] (LDOCE). Zostali sme priatelia.

[11] She may be [an ideal person to look after the children] (LDOCE). Môže byt' ideálnou osobou, ktorá sa môže postarat' o deti.

[12] The task proved [difficult] (LDOCE). Úloha sa ukázala ako t’ažká.

[13] Slowly my eyes became [accustomed to the darkness] (LDOCE). Moje oči si pomaly zvykali na tmu.

[14] He is [what he always wanted to be] (LDOCE). Je tým, kým vždy chcel byt'.

Podmetový doplnok (subject complement), ako už bolo konštatované, doplńna význam podmetu a vyskytuje sa vo vetnom vzorci SVC (podmet-sloveso-komplement). Môže byt' vyjadrený nominálnou frázou, adjektívnou frázou, ale aj nominálnou vedlajšou vetou. Vo vetných príkladoch [10] a [11] je podmetový doplnok vyjadrený nominálnymi frázami (noun phrases). Vo vete [10] je vyjadrený jednoduchou nominálnou frázou friends (priatelia), vo vete [11] má formu zloženej nominálnej frázy, v ktorej má post-modifikátor štruktúru vedlajšej vety s neurčitým slovesným tvarom an ideal person to look after the children (ideálna osoba, ktorá sa môže postarat' o deti). Vo vetných príkladoch [12] a [13] je podmetový doplnok vyjadrený adjektívnymi frázami (adjective phrases). Vo vete [12] je vyjadrený jednoduchou adjektívnou frázou difficult (t’ažký/á). Avšak, vo vete [13] je vyjadrený zloženou adjektívnou frázou accustomed to the darkness (zvyknutý/á na tmu). Vo vete [14] je zdôraznené, že podmetový doplnok môže byt' v angličtine vyjadrený aj vedl'ajšou vetou what he always wanted to be (tým, kým vždy chcel byt'). Z uvedenej analýzy tiež vyplýva, že sponové slovesá si vyžadujú doplnenie podmetovým doplnkom nielen $\mathrm{v}$ anglickom, ale aj $\mathrm{v}$ slovenskom, typologicky odlišnom jazyku. Slovenské ekvivalenty viet [10] -[14] by boli bez podmetového doplnku gramaticky a významovo neúplné.

Druhým vetným členom, ktorý sa môže vyskytovat' po sponovom slovese vo vetnom vzorci SVA (podmet - sloveso - príslovkové určenie) je obligatórne príslovkové určenie, ktoré môže byt' vyjadrené príslovkovou frázou (adverb phrase), prepozicionálnou frázou (prepositional phrase) a tiež vedl'ajšou vetou s určitým a neurčitým slovesným tvarom (finite clause, non-finite clause).

[15] The principal's [in his office] (LDOCE).

Riaditel' je v jeho kancelárii. 
[16] The keys are [where you left them] (LDOCE).

Kl'úče sú, kde si ich nechal/a.

Po sponovom slovese to be (byt') je príslovkové určenie vo vetnom príklade [15] vyjadrené predložkovou frázou in his office (v jeho kancelárii). Avšak, vo vete [16] je to isté sponové sloveso doplnené obligatórnym príslovkovým určením vyjadreným vedl'ajšou vetou $\mathrm{s}$ určitým slovesným tvarom where you left them (kde si ich nechal/a). Z analýzy slovenských ekvivalentov viet [15] a [16] tiež vyplýva, že sponové sloveso to be si vyžaduje komplementáciu obligatórnym príslovkovým určením nielen $\mathrm{v}$ anglickom, ale aj v slovenskom jazyku.

\section{Monotranzitívna komplementácia}

Sloveso $\mathrm{v}$ monotranzitívnej komplementácii si vyžaduje doplnenie priamym predmetom vo vetnom vzorci SVO (podmet - sloveso - predmet). Priamy predmet v tomto komplementačnom type môže byt' vyjadrený nominálnou frázou a vedl'ajšími vetami s určitým a neurčitým slovesným tvarom (finite clauses, non-finite clauses).

[17] Brad's car needs [new tires] (LDOCE).

Bradove auto potrebuje nové pneumatiky.

[18] We know [that greenhouse gases can affect the climate] (LDOCE).

Vieme, že skleníkové plyny môžu ovplyvnit' klímu.

[19] The plants need [watering once a week] (LDOCE).

Rastliny potrebujú zalievanie raz za týždeň.

Priamy predmet v monotranzitívnej komplementácii vo vete [17] je vyjadrený nominálnou frázou new tires (nové pneumatiky). Avšak, priamy predmet vo vetnom vzorci SVO vo vete [18] je vyjadrený vedl'ajšou vetou s určitým slovesným tvarom that greenhouse gases can affect the climate (že skleníkové plyny môžu ovplyvnit' klímu). Priamy predmet vo vete [19] je tiež vyjadrený vedl'ajšou vetou, avšak vedl'ajšou vetou s neurčitým slovesným tvarom.

\section{Ditranzitívna komplementácia}

V ditranzitívnej komplementácii (ditransitive complementation) je sloveso doplnené nepriamym a priamym predmetom vo vetnom vzorci SVOO (podmet - sloveso predmet - predmet). Quirk a kol. (1985) používajú symbol O na označenie nepriameho a aj priameho predmetu. Avšak, Carter and McCarthy (2006) používajú symbol IO na označenie nepriameho predmetu a symbol DO na označenie priameho predmetu. Downing a Locke (2006) používajú symbol Oi na označenie nepriameho predmetu a symbol Od na označenie priameho predmetu. Downing a Locke (2006), Biber a kol. (1999), na rozdiel od Quirka a kol. (1985), Cartera a McCarthyho (2006), používajú aj symbol Op na označenie prepozicionálneho predmetu.

Nepriamy predmet je vo vetnom vzorci SVOO (podmet-sloveso-predmet-predmet) zvyčajne vyjadrený nominálnou frázou, avšak výnimočne môže byt' vyjadrený aj vedl'ajšou vetou s určitým slovesným tvarom. Priamy predmet môže byt' v ditranzitívnej komplementácii vyjadrený nominálnou frázou, ale aj vedl'ajšou vetou s určitým a neurčitým tvarom.

[20] The light tells [you] [when the machine is ready] (LDOCE). Svetlo ta/vás upozorní, ked' je stroj pripravený. 
[21] He told [us] [to sit down] (LDOCE).

Povedal nám, aby sme si sadli.

[22] Tell [me] [your phone number] (LDOCE).

Povedz mi tvoje telefónne číslo.

Nepriamy predmet vo vetnom príklade [20] je vyjadrený nominálnou frázou you ('’a/vás) a priamy predmet je vyjadrený vedl'ajšou vetou s určitým slovesným tvarom when the machine is ready (ked' je stroj pripravený). Podrad'ovacia spojka when (ked', kedy) uvádza $\mathrm{v}$ angličtine zvyčajne príslovkové vety časové, avšak v tomto vetnom príklade uvádza nominálnu vedlajšiu vetu vo funkcii priameho predmetu. Nepriamy predmet vo vetnom príklade [21] je tiež vyjadrený nominálnou frázou us (nám) a priamy predmet je vyjadrený vedlajšou vetou s neurčitým slovesným tvarom to sit down (aby sme si sadli). Vo vetnom príklade [22] je zdôraznené, že priamy predmet $\mathrm{v}$ ditranzitívnom type komplementácie môže byt' vyjadrený aj nominálnou frázou your phone number (tvoje telefónne číslo).

\section{Komplexne-tranzitívna komplementácia}

Komplexne-tranzitívna komplementácia (complex transitive complementation) si vyžaduje doplnenie (komplementáciu) dvomi obligatórnymi vetnými členmi, priamym predmetom (direct object) a podmetovým doplnkom (object complement) vo vetnom vzorci SVOC (podmet- sloveso - predmet- komplement). Druhým vetným vzorcom v tomto type komplementácie je vzorec SVOA (podmet - sloveso - predmet príslovkové určenie). Príslovkové určenie v tomto type komplementácie nemôže byt' vynechané, veta by bola po formálnej a významovej stránke neúplná.

Ak porovnávame komplexne-tranzitívnu komplementáciu prezentovanú Quirkom a kol. (1985) s komplexne-tranzitívnou komplementáciou Cartera a McCarthyho (2006), môžeme konštatovat', že obaja lingvisti používajú rovnaký termín na označenie vetného člena, ktorý nasleduje po priamom predmete $\mathrm{v}$ uvedenom type komplementácie, a to je predmetový doplnok (object complement). Avšak, rozdiel medzi týmito lingvistami je $\mathrm{v}$ terminológii, ktorú používajú na označenie formálnej, gramatickej realizácie predmetového doplnku. Quirk a kol. (ibid.) používajú termín adjektívny komplement (adjectival complement) na označenie predmetového doplnku vyjadreného adjektívnou frázou a termín

nominálny komplement (nominal complement) na označenie predmetového doplnku vyjadreného nominálnou frázou. Avšak, Carter a McCarthy (ibid.) používajú termín adjektívna fráza ako predmetový doplnok (adjective phrase as object complement), alebo termín nominálna fráza ako predmetový doplnok (nominal phrase as object complement) na označenie gramatickej realizácie predmetového doplnku vo vetnom vzorci SVOC (podmet- sloveso - predmet- komplement).

Vetný člen, ktorý nasleduje po priamom predmete vo vetnom vzorci SVOA (podmetsloveso-predmet-príslovkové určenie) označujú Quirk a kol. (ibid.) termínom príslovkové určenie (adverbial). Avšak, Carter a McCarthy (ibid.) označujú ten istý vetný člen $\mathrm{v}$ tomto type komplementácie termínom lokatívny komplement (locative complement).

V našej analýze vetných príkladov budeme používat' terminológiu Quirka a kol. (1985).

[23] The continuous noise was driving [me] [crazy] (LDOCE).

Nepretržitý hluk ma privádzal do šialenstva.

[24] We named [our daughter] [Sarah] (LDOCE). 
Našej dcére sme dali meno Sarah.

[25] He left [the keys] [where he can find them] (LDOCE).

Nechal klúče tam, kde ich môže nájst'.

[26] George kept [a bottle of whiskey] [under his bed].

Juraj nechal fl'ašu whisky pod postel'ou.

Predmetový doplnok (object complement) dopíňa význam priameho predmetu a môže byt' vo vetnom vzorci SVOC formálne vyjadrený nominálnou frázou (nominal phrase), adjektívnou frázou (adjective phrase), alebo vedlajšou vetou s určitým a neurčitým slovesným tvarom (finite clause, non-finite clause). Príslovkové určenie môže byt' vo vetnom vzorci SVOA vyjadrené prepozicionálnou frázou (prepositional phrase), alebo vedl'ajšou vetou s určitým a neurčitým slovesným tvarom (finite clause, non-finite clause).

Vo vetnom príklade [23] je predmetový doplnok vo vetnom vzorci SVOC vyjadrený adjektívnym komplementom (adjectival complement) crazy (šialený) a vo vete [24] je vyjadrený nominálnym komplementom (nominal complement) Sarah. Vo vetnom vzorci SVOA vo vete [25] je obligatórne príslovkové určenie vyjadrené vedl'ajšou vetou s určitým slovesným tvarom a vo vete [26] je tento obligatórny vetný člen vyjadrený prepozicionálnou frázou.

\section{Záver}

$\mathrm{V}$ štúdii boli analyzované, porovnávané a diskutované rôzne prístupy lingvistov $\mathrm{k}$ problematike slovesnej komplementácie a valencie $\mathrm{v}$ angličtine. Uviedli sme, že Quirk a kol. (1985), Greenbaum a Nelson (2002), Carter a McCarthy (2006) používajú termín slovesná komplementácia. Naopak, Biber a kol. (1999), Huddleston a Pullum (2002), Downing a Locke (2006), Wekker a Haegeman (1985) používajú termín valencia. Podl'a teórie slovesnej komplementácie patria medzi komplementy slovesa iba tie obligatórne časti vety (komplementy), ktoré nasledujú po slovese. Avšak, podl'a valenčnej teórie patria medzi komplementy slovesa nielen obligatórne časti vety, ktoré nasledujú po slovese, ale aj komplement, ktorý má v anglickej oznamovacej vete postavenie pred slovesom.

V štúdii bolo tiež objasnené, a na vetných príkladoch excerpovaných z Longman Dictionary of Contemporary English Online ukázané, že termín komplement sa používa $\mathrm{v}$ anglickej syntaxi vo viacerých významoch. Týmto termínom označujeme komplementy ako obligatórne vetné členy po sponových slovesách (podmetový doplnok alebo príslovkové určenie) a po komplexne-tranzitívnych slovesách (priamy predmet a predmetový doplnok, alebo priamy predmet a príslovkové určenie). Termínom komplement sa $\mathrm{v}$ anglickej syntaxi označujú obligatórne vetné členy vyskytujúce sa aj po iných slovesách, nielen po sponových a komplexne tranzitívnych slovesách.

Analýzou vybraných akademických zdrojov literatúry zaoberajúcich sa problematikou slovesnej komplementácie a valencie v angličtine sme dospeli k záveru, že ani názory lingvistov na typy slovesnej komplementácie nie sú jednotné. Carter a McCarthy v gramatike Cambridge Grammar of English (2006) uznávajú štyri typy slovesnej komplementácie - monotranzitívnu, ditranzitívnu, komplexne- tranzitívnu a sponovú komplementáciu. Quirk a kol. v gramatike A Comprehensive Grammar of the English Language (1985) tiež tvrdia, že v angličtine sú štyri typy slovesnej komplementácie, a to monotranzitívna, ditranzitívna, komplexne-tranzitívna a sponová komplementácia.

Avšak, Biber a kol. v gramatike Longman Grammar of Spoken and Written English (1999) a Downing a Locke v gramatike English Grammar. A University Course (2006) rozlišujú pät' typov komplementácie: intranzirívnu, monotranzitívnu,

XLinguae, Volume 12, Issue 2, April 2019, ISSN 1337-8384, eISSN 2453-711X 
ditranzitívnu, komplexne-tranzitívnu a sponovú komplementáciu. Wekker a Haegeman v gramatike A Modern Course of English Syntax (1985) rozlišujú až sedem typov komplementácie, a to intranzitívnu, sponovú, monotranzitívnu, ditranzitívnu, komplexne-tranzitívnu, intranzitívnu + prepozicionálna fráza, tranzitívnu + prepozicionálna fráza. V štúdii sú tiež analyzované dôvody odlišného počtu typov komplementácie vo vybraných lingvistických zdrojoch literatúry.

V štúdii bola tiež analyzovaná a porovnávaná nejednotná terminológia týkajúca sa obligatórnych vetných členov vo vybraných lingvistických zdrojoch literatúry. Náležitá pozornost' bola tiež venovaná analýze a komparácii gramatickej realizácie obligatórnych vetných členov vo vetnom vzorci SVC (podmet-sloveso-komplement) a vo vetnom vzorci SVA (podmet-sloveso-príslovkové určenie). V štúdii bolo na autentických vetných príkladoch preukázané, že podmetový doplnok môže byt' vyjadrený nominálnou frázou, adjektívnou frázou, ale aj nominálnou vedl'ajšou vetou. Obligatórne príslovkové určenie vo vetnom vzorci SVA (podmet-sloveso príslovkové určenie) môže byt' vyjadrené príslovkovou frázou, prepozicionálnou frázou a tiež vedl'ajšou vetou s určitým a neurčitým slovesným tvarom.

Pozornost' bola tiež venovaná monotranzitívnej komplementácii, v ktorej si sloveso vyžaduje doplnenie priamym predmetom vo vetnom vzorci SVO (podmet-slovesopredmet). Vo vetných príkladoch excerpovaných $\mathrm{z}$ Longman Dictionary of Contemporary English Online sme preukázali, že priamy predmet môže byt' v tomto komplementačnom type vyjadrený nominálnou frázou a vedl'ajšou vetou s určitým a neurčitým slovesným tvarom. Zdôraznili sme tiež, že v slovenskom jazyku, ktorý je typologicky odlišný od anglického jazyka, si slovesá vyžadujú doplnenie (komplementáciu) tými istými vetnými členmi ako v anglickom jazyku.

Pozornost' bola tiež venovaná špecifickým črtám ditranzitívnej komplementácie s dôrazom na odlišné označenie priameho predmetu, nepriameho predmetu a prepozicionálneho predmetu $\mathrm{v}$ analyzovaných lingvistických zdrojoch literatúry. Priamy predmet môže byt' $\mathrm{v}$ ditranzitívnej komplementácii vyjadrený nominálnou frázou, ale aj vedl'ajšou vetou $\mathrm{s}$ určitým a neurčitým tvarom, čo bolo $\mathrm{v}$ štúdii preukázané.

V analýze komplexne-.tranzitívnej komplementácie sme preukázali, že terminológia týkajúca sa obligatórnych vetných členov vo vetnom vzorci SVOC a SVOA nie je v analyzovaných zdrojoch literatúry jednotná. Odlišnost' terminológie $\mathrm{v}$ uvedených zdrojoch literatúry sa prejavila nielen v terminológii týkajúcej sa vetných členov, ale aj v terminológii týkajúcej sa gramatickej realizácie týchto vetných členov.

\section{Bibliographic references}

BIBER, D. et al. 2011. Longman Grammar of Spoken and Written English. Harlow: Pearson Education Limited. ISBN 978-0-582-23725-4.

BRINTON, L.J. 2000. The Structure of Modern English: A linguistic introduction. Amsterdam: John Benjamins Co. ISBN 9027225672.

CARTER, R. A. - HUGHES, R. - McCARTHY, M. J. 2000. Exploring Grammar in Context: Grammar reference and practice. Cambridge: Cambridge University Press. ISBN 978-0-521-56844-9.

CARTER, R. A. - McCARTHY, M. J. 2006. Cambridge Grammar of English. Cambridge: Cambridge University Press. ISBN-13 978-0-521-58846-1.

DOWNING, A. - LOCKE, P. 2006. English Grammar. A University Course. Second edition. Abingdon: Routledge. ISBN 978- 0-415-28787-6.

GREENBAUM, S. 1989. A College Grammar of English. London: Longman. ISBN 0-582-28597-6.

GREENBAUM, S. 1996. The Oxford English Grammar. New York: Oxford University Press Inc. ISBN 0-19-861250-810 987.

GREENBAUM, S. - QUIRK, R. 1990. A Student's Grammar of the English Language. Harlow: Longman. ISBN 0-582-05971-2. 
GREENBAUM, S. - Nelson, G. 2002. An Introduction to English Grammar. Pearson Education Limited. ISBN 978- 0- 582-43741-8.

HUDDLESTON, R. 1988. English Grammar: An Outline. Cambridge: Cambridge University Press. ISBN-13: 978-0521538213.

HUDDLESTON, R. 1984. Introduction to the Grammar of English. Cambridge: Cambridge University Press. ISBN-13: 978-0521297042.

HUDDLESTON, R. - PUllUM, G. K. 2002. The Cambridge Grammar of the English Language. Cambridge: Cambridge University Press. ISBN 9780521431460.

Longman Dictionary of Contemporary English Online. Available online: http:/www. ldoceonline.com.

McCAWLEY, J. 1988. The Syntactic phenomena of English. Chicago: University of Chicago Press. ISBN 9780226556277.

O'GRADY, W. D. et al. 2011. Contemporary Linguistics. Pearson Longman. ISBN $978-1405899307$.

QUIRK, R. et al. 1985. A Comprehensive Grammar of the English Language. Harlow: Longman Group Limited. ISBN 0-582-51734-6.

QUIRK, R. - GREENBAUM, S. - LEECH, J. - SVARTVIK, J. 1972. A Grammar of Contemporary English. London: Longman. ISBN 058252444.

WEKKER, H. - HAEGEMAN, L. 1985. A Modern Course in English Syntax New York: Routledge. ISBN 0-415-03684-4.

Words: 5070

Characters: 37889 (21,05 standard pages)

assoc. prof. PhDr. L’udmila Jančovičová, CSc.

Department of British and American Studies

University of Ss. Cyril and Methodius in Trnava

Nám J. Herdu 2, 91701 Trnava

Slovakia

ludmila.jancovicova@ucm.sk 